\title{
MLL/LASP1 Fusion Protein
}

National Cancer Institute

\section{Source}

National Cancer Institute. MLL/LASP1 Fusion Protein. NCI Thesaurus. Code C99336.

A fusion protein encoded by the MLL/LASP1 fusion gene. This protein is comprised of the $\mathrm{N}$-terminal half of the histone-lysine $\mathrm{N}$-methyltransferase MLL protein, including the AT hook DNA binding domain and the DNA methyltransferase domain, fused with the Cterminal SH3 domain of the LIM and SH3 domain protein 1. 